\title{
Generalization of Many Studies on the Introduction of Non-Enforcement of Bedsore Measures
}

\author{
Tetsuhiko Kimura ${ }^{1}$ \\ ${ }^{1}$ Japan rehabilitation technical school (E-mail:takizawa@biophilia.biz)
}

\begin{abstract}
Decubitus is a disorder which is not cured easily. However, health professionals who have treated many cases know that the disorder can be prevented. The author has been proposing to medical societies how to prevent decubitus based on a scientific basis from around the middle of the 1960s. The proposition is based on the method of coloring by the ammonium rhodanide and on the KOSIAK method of a balloon pressure measurement; both reported to be giving almost the same result. Many studies on the mechanisms underlying decubitus and/or bedsore development have been performed from a 100 years ago. There are many elucidated facts concerning the pathology and biochemistry of decubitic changes in scientific journals. Nevertheless, the number of patients with decubitus, who would be able to prevent it, has not decreased despite the spread of knowledge. Our study group has been working for years on how to improve the present poor condition regarding the frequency of decubitus and how to find out any possible solution. The evil of the bedsore and the ways of its prevention have been proposed through the author's academic activity for 40 years. In order to acquire a solution for today's situation, we have striven for prevention of decubitus for many years. Then, the Japanese Ministry of Health, Labour and Welfare introduced the policy that was named "the non-enforcement of bedsore measures" for the prevention of decubitus in inpatient medical institutions, which reduces income for the health insurance companies. By the enforcement of the policy, the medical institution laid emphasis on the prevention. Then, the hospitalization practice for the decubitus prevention measures was renewed for additional two years after its introduction. Our investigation on the preventive effects was conducted with aid of the Grant-in-Aid for Scientific Research (KAKENHI) by MEXT in 2005-2006 and the Association for Technical Aids research grant in 2006-2007. The research grants acquisition and study implementation were done mainly in Takizawa. Nagaoka, Takizawa and Murakami reported the development of a device to use, study methods and contents, and details of the results. We report what kind of influence was caused by the introduction of bedsore measures non-enforcement policy on the basis of a questionnaire survey.
\end{abstract}

Keywords: prevent, decubitus, bedsore, demerit mark policy for the non-measures to the prevention of decubitus inpatient, Biophilia rehabilitation, Motivative exercise

\footnotetext{
Received: June 22, 2010, Reviewed: December 15, 2010, Published: March 31, 2011

The Japanese article of the Biophilia Rehabilitation Journal was published as above.

Reprint and publish permission date in the review for the BIOPHILIA: February 17, 2015

The Biophilia editorial board obtained the publication request and copyright holder's permission, committed English abstract for the Japanese article, reprinted it after the review and published this article.
} 


\title{
裖瘡対策未実施減算政策導入に係る諸研究の総括
}

\author{
木村哲彦 \\ 日本リハビリテーション専門学校＼cjkstart校長
}

\section{1. 緒言・要旨}

裖瘡は治り難いもの，そして治し難いもの，然し予防できるものと言うことは多くの症例を扱 ってきた医療者は知っていた。それを科学的根拠に基づいて学会に提言したのは 1960 年代の半ば 頃からであった。著者はロダンアンモン発色方で ${ }^{1)},{ }^{2)}$, KOSIAK はバルーンによる圧力測定を根 拠にほぼ同じ結果を報告している ${ }^{3)}$ 。

裷瘡，床擦れと言われた 100 年前より発生原因，物理学的対策，薬物学的対策について多くの 研究が成され, 病理学的な特性, 生化学的特性に関する病態についても判明した事実は多( 4), 5), 6)，7， 8)，9，10，11，12，13，14，15)，16，17)，18)。裖瘡の発生機序，組織学的変化などに関する報告は 多くの学術雑誌に見られたが，裖瘡についての知識の普及に反し，予防寸れば予防可能である筈 の裖瘡患者の数の減少寸る気配は一向に薄く, 厚生労働省も健康保険点数に於いて未対策の医療 機関の入院患者に対する減点政策を採るに至った。更に 2 年後の改正時に予防対策を前提とした 入院点数を付するに至っている。

然し，裖瘡管理が行き届か女医療機関に対し，健康保険点数減算措置がとられた後に，医療機 関は本腰を入れて予防に力を投入するところとなった結果，行政は素早く減算措置から予防体制 を整えた医療機関に保険点数の加算を行う所となった。

我々研究班は, 予防の至らぬ点を憂い, 現状を究めて解決策を得んと意図し, 長年にわたり啓 発に努めてきた所であるが，平成 17-18 年文部科学省科研費 ${ }^{19)}$ と平成 18-19 年財団法人テクノエ イド協会研究助成金 ${ }^{20)}$ により，予防効果に関寸る研究に従事した。

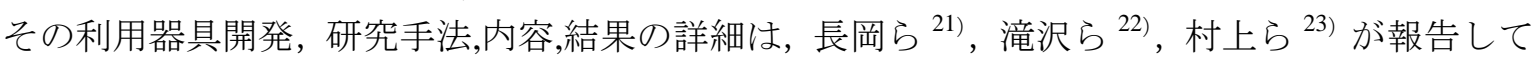
いる。特に長岡は, 長岡病院グループは KOSIAK の提唱寸る徐圧による予防の効果を立証し,「コ ジャックの法則（局所圧力 $200 \mathrm{mmHg}$ 以下・2 時間以内の体位変換）に則して，体位変換を実施 すれば裖瘡の発生を見ない」を実現した病院の状況について報告した ${ }^{24)}{ }^{25)}$ 。しかし，一般の医 療機関に於いては 40 年来学会等を介して我々が裖瘡の弊害と予防の可能なことを提唱してきた ことが殆どの医療機関では生かされてこなかった実態がある。

本稿では以下，実施したアンケート調查から，政策として，裖瘡対策未実施減算導入がどのよ うな影響を与えたかを述べる。

著者を含め, 直接データ採集に関わった本研究グループを構成するメンバーは次に挙げる医療 機関及び人員による。

平成 17-18 年度文部科学省科研研究：(当時) 木村哲彦（国際医療福祉大学・大学院・教授), 滝沢茂男(リハビリエイド有限会社・バイオフィリア研究所・研究員), 長岡健太郎(医療法人湘南 健友会長岡病院・診療科・理事長)，牛澤賢二(産能大学・経営情報学部・教授)，山下和彦(東京 電機大学・工学部情報メディア学科・ポスドク), 森田能子(川崎病院・リハビリテーション科・ 部長), 村尾俊明（財団法人テクノエイド協会・常務理事）

平成 18-19 年度財団法人テクノエイド協会研究: (当時) 木村哲彦(前出), 滝沢茂男(バイオフィ リア研究所有限会社・研究所長), 森田能子(前出), 岡本雄三(医療法人帰篇会岡本病院 院長), 長岡健太郎(前出), 長澤弘(神奈川県立保健福祉大学リハビリテーション学科・教授), 牛澤賢二(前 出), 川合秀治(社団法人全国老人保健施設協会副会長), 和田里佳(立花整形外科通所リハビリテー ションセンター・所長), 白澤卓二(東京都老人総合研究所分子老化研究グループ・研究部長), 塚 田邦夫(高岡駅南クリニック院長), 足立かおる(岡本病院副院長), 村上亜紀(湘南看護専門学校専 任教員)，高田一（横浜国立大学教授） 


\section{2. 政策の変遷}

裖瘡対策未実施減算（平成 14 年 10 月）は，1）専任の医師・看護師から構成される裖瘡対策于 一ムを設置していること，2）必要と判断した入院患者全てに裖瘡対策診療計画書を作成し実施す ること，3）患者の状態に応じた体圧分散マットレス等を用意して適切に選択し使用する体制を整 備，を対策とし，していなければ（未実施） 1 日 5 点を全入院患者数で減算とする初めての罰則 規定であった。

裖瘡対策改訂（H16. 4）により，危険因子に対して適切な裤瘡対策の計画を立案して実施をす れば，その患者 1 入院につき 20 点の加算とし，現在実施中である。更にWOC資格のある専従看 護師加算 500 点の政策となっている。このような施策の中，現場ではどのような効果があったか を検証すべく, 研究を行った。

\section{3. 調查対象}

\section{1. 回答者}

我々は, 全国 2016 施設に施設責任者用と現場の実務者用の 2 種類のアンケートを郵送し，詳細 は村上らによるが，施設の責任者 259 件，現場の従事者 561 件から回答を得て，その結果を分析 した。回答者の属する病院・施設の種類別回答数を表 1 に示した。アンケートの回答率は $11 \%$ で あった。

回答者の特性であるが，「裖瘡対策委員会の委員あるいは裖瘡チーム員ですか」の問いに対し， 郵送調査の有効サンプルは合計 224 件で, 協力病院全数調查有効サンプルを合計すると 539 件で ある。表 2 に示したとおり，郵送調査は $85 \%$ が裖瘡対策委員会の委員あるいは裖瘡チーム員であ るが，全数調査は $43 \%$ と差があった。郵送調查の回答者と全数調査の回答者の構成の特徵が反映 されている。本研究で，郵送調査と協力病院の全職員による調査が出来たことは，各施設の代表 的勤務者による回答という特殊性を緩和する面でも大きな意味があるといえる。

\section{表1. 病院・施設の種類}

\begin{tabular}{llr}
\hline & 度数 & パーセント \\
\hline 1. 特定機能病院 & 8 & $3.1 \%$ \\
2. 一般病院 & 68 & $26.6 \%$ \\
3. 療養病床を持つ病院 & 108 & $42.2 \%$ \\
4. 回復期リハビリテーション病院 & 5 & $2.0 \%$ \\
5. 介護老人福祉施設 & 66 & $25.8 \%$ \\
6. 介護老人保健施設 & 1 & $0.4 \%$ \\
\hline
\end{tabular}

表2. 裖瘡対策委員会の委員または裖瘡チーム員か?

\begin{tabular}{lcccc}
\hline \multicolumn{4}{c}{ 郵送 } & \multicolumn{3}{c}{ 全数 } \\
\hline 1. はい & 179 & $80 \%$ & 234 & $43 \%$ \\
2. いいえ & 46 & $20 \%$ & 305 & $57 \%$ \\
\hline
\end{tabular}

\section{2. 裖瘡委員会と裖瘡チーム}

病院の裖瘡対策委員会と裖瘡チームの関係で, チーム全員が委 員会に入っているとの回答は 225 件中 8 割であった。表 3 に示 した。裖瘡チームには看護師は $100 \%$ 近く（介護老人福祉施設 には看護師が常勤でないとの回答があった。），ついで医師と栄養士が多く，栄養士の重要性が反 映していると思われる。ただし回診に関して言えば，看護師は 204 件と $100 \%$ 近く，医師が 185 件で必須の構成員で栄養士は 40\%程度である。ここから栄養士は危険因子を持つ患者発見後に活
表3. 裖瘡チーム員は全員が裖瘡対策 委員会に入っていますか ?

\begin{tabular}{lrr}
\hline & 度数 & パーセント \\
\hline 1. はい & 179 & $80 \%$ \\
2. いいえ & 46 & $20 \%$ \\
\hline
\end{tabular}

\begin{tabular}{lrr}
\multicolumn{1}{c}{ 職種 } & 人数 & \multicolumn{2}{c}{$\begin{array}{c}\text { 回答に対する } \\
\text { パーセント }\end{array}$} \\
\hline 1. 医師 & 197 & $83 \%$ \\
2. 看護師 & 234 & $99 \%$ \\
3. 薬剂師 & 124 & $52 \%$ \\
4. PT & 76 & $32 \%$ \\
5. OT & 34 & $14 \%$ \\
6. 栄養士 & 181 & $76 \%$ \\
7. 介護士 & 85 & $36 \%$ \\
8. MSW & 15 & $6 \%$ \\
9. 事務職 & 92 & $39 \%$ \\
10. その他 & 33 & $14 \%$ \\
養士が多く, 栄養士の重要性が反 \\
204 件と 100\%近く, 医師が 185 \\
は危険因子を持つ患者発見後に活
\end{tabular}

表4. 裖瘡チ一ムの構成職種 
躍の場があると考えられる。

\section{3. 褲瘡委員会のメンバー・褯瘡回診参加メンバー}

裖瘡チーム構成メンバーは 10 人から 15 人がもっとも多く $73 \%$ を占め，会の開催頻度は毎月 1 回が約 80\%でであった。表

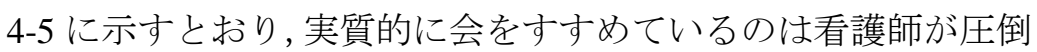
的に多い。注目すべきは看護師，医師についで栄養士が 75\%を 占めている。委員会の業務は, 各病院でその位置づけが異なる が，裖瘡の発生患者数やその転帰報告などの院内裖瘡患者のデ 一夕管理から具体的な裖瘡対策などについて示唆するなど多岐 に渡っていた。なお，「委員会・裖瘡回診でどのような対応方法 を定めますか?」の問いに，209 件の回答があり，「1.栄養」が 158 件を占めた。

\section{4. 裖瘡に関する看護師について}

看護体制では認定看護師は少なく, ハイリスク加算 がとれる施設は少ない。表 6 に示した。看護師がリー ドしている裖瘡対策であるが, 実際に役付で裖瘡専任 あるいは専従だと，それぞれ $30 \% ， 17 \%$ と少ない。

\section{4. 裖瘡予防用福祉用具について}

\section{1. 減圧マットレスの整備}

減圧マットレスの整備は，管理者の半数がまだ十分には充足し ていないと答えている。表 7 に示した。一方で，院内のマットの 把握は $85 \%$ でできていると回答している。表 8 に示した。また, 実務者の 6〜7 割は，用具が増えたことを評価している。

\section{2. ベッドマットの選択}

ベッドマットの選択方法に関し 504 件の回答が あり，表 9 に示した。実際にはこれら混在してい る可能性が高い。マットの選択は，裖瘡がある場 合には正しければてき面に改善がみられること から重要性が分かる。

\section{3. ベッド上で利用する用具}

利用している用具 (マットレス) についての回 答を表 10 に示した。エアマットレス 196 件，圧 切替型エアマットレス 121 件，上敷きマットレ ス 96 件などが良く利用されている。9.その他に ついては 39 件回答があり，体圧分散マットレ ス 6 件, 体圧分散マット 4 件, 天然ゴムマット 2 件, 無圧マット 2 件, オムニマット 2 件, そ の他コンフォートマット, マキシフロートなど があった。その他の利用器具の回答では, ベッ ド上で利用する体圧減少器具について, クッショ ン 216 件, ウレタンスポンジ 155 件, ビーズ 151
表5. 回診メンバー

\begin{tabular}{lrr}
\hline \multicolumn{1}{c}{ 職種 } & 人数 & $\begin{array}{r}\text { 回答に対する } \\
\text { パーセント }\end{array}$ \\
\hline 1. 医師 & 185 & $90 \%$ \\
2. 看護師 & 204 & $100 \%$ \\
3. 薬剤師 & 56 & $27 \%$ \\
4. PT & 34 & $17 \%$ \\
5. OT & 16 & $78 \%$ \\
6. 栄養士 & 86 & $42 \%$ \\
7. 介護士 & 27 & $13 \%$ \\
8. MSW & 1 & $5 \%$ \\
9. 事務職 & 12 & $59 \%$ \\
10. その他 & 9 & $44 \%$ \\
\hline
\end{tabular}

表6. 裖凔に関する看護師の配置

\begin{tabular}{lrrrr}
\hline & 有 & $\%$ & 無 & $\%$ \\
\hline 認定看護師 & 8 & $3 \%$ & 225 & $97 \%$ \\
専任看護師 & 69 & $30 \%$ & 158 & $70 \%$ \\
専従看護師 & 39 & $17 \%$ & 186 & $83 \%$ \\
\hline
\end{tabular}

表7. 裖瘡マット(予防/治療) 数は充足 しているか?

\begin{tabular}{lrr}
\hline & 度数 & パーセント \\
\hline 1. はい & 124 & $49.7 \%$ \\
2. いいえ & 125 & $50.2 \%$ \\
\hline
\end{tabular}

表8. 全マットの使用状況は把握されて いるか?

\begin{tabular}{lrr}
\hline & 度数 & 有効パーセント \\
\hline 1. はい & 211 & $81.0 \%$ \\
2. いいえ & 37 & $14.3 \%$ \\
\hline
\end{tabular}

表9. ベッドマットの選択方法

\begin{tabular}{lrr}
\hline & 度数 & パーセン卜 \\
\hline 1. マニュアルどおりに選択する & 229 & $45.4 \%$ \\
2. 余っているのを使用する & 159 & $31.5 \%$ \\
3. 裖瘡回診で相談する & 194 & $38.5 \%$ \\
4. その他 & 82 & $16.3 \%$ \\
\hline
\end{tabular}

表10. 利用しているマットレス

\begin{tabular}{lrr}
\hline & 度数 & パ-セ2 \\
\hline 1. 上敷きマットレス & 96 & $37.6 \%$ \\
2. エアマットレス & 196 & $76.9 \%$ \\
3. 一体成形型エアマット & 33 & $12.9 \%$ \\
4. セル型エアマット & 65 & $25.5 \%$ \\
5. 圧切替型エアマットレス & 121 & $47.5 \%$ \\
6. ウレタンフォームエアマット & 83 & $32.5 \%$ \\
7. ウオーターベッド & 4 & $1.6 \%$ \\
8. ウオーターマット & 6 & $2.4 \%$ \\
9. その他 & 41 & $16.1 \%$ \\
\hline
\end{tabular}


件などが良く利用されている。回答を表 11 に示 した。

ベッド上で利用する体位支持用具については, クッション 228 件, ビーズ 155 件, ウレタンスポ ンジ 135 件，タオル 106 件などが良く利用されて いる。回答を表 12 に䌕めた。クッション利用は 長岡病院の利用実態を反映しているものと考え られる。

\section{4. 車椅子又は座位で利用する用具}

車椅子又は座位で利用する体圧減少器具では, クッション 174 件, ウレタンスポンジ 136 件など が良く利用されていることが分かった。また体位 支持用具についてクッション 191 件, リクライニ ング車椅子 171 件, ウレタンスポンジ 107 件など が良く利用されていることが分かった。回答を表 13 に緾めた。

骨突出部位の圧迫除去の用具について, クッシ ヨン 153 件, リクライニング車椅子 139 件, ウレ タンスポンジ 117 件などが良く利用されているこ とが分かった。

\section{5. 器具利用教育を行うシステム}

器具利用教育実施に関する回答を表 14 に纏めた。 家族・本人等に対して，「2. いいえ」が 222 件とほ とんど無いことが分かった。医師・看護師・介護士 等に対しても実施されている機関は 34\%であり, 家 族相手の教育システムに至っては $10 \%$ 以下である。 何らかのシステムを提供できるように整備する必 要性を示唆しているといえる。講師は業者に所属す るものが $60 \%$ であった。有料研修に費用負担をして くれるのは 70\%と高い。まだスタッフへの研修がや っとで用具の正しい使用法など家族への指導がで きている病院はまだごくわずかである。

\section{6. 裖瘡予防に用いる用具について}

現場実務者にとっての裖瘡予防に用いる用具に ついて 11 項目の調査を行った。表 15 に緒めた。現 場実務者は郵送回答者 $60 \%$ と比べ研修を受けた者 が少なく $42 \%$ であった。用具使用の介護業務軽減 への影響については現場実務者の $73 \%$ ，郵送回答 では79\%が「楽になった」とした。
表11. 利用しているその他の器具

\begin{tabular}{lrr}
\hline & 度数 & パーセン \\
\hline 1. 羽枕 & 33 & $12.9 \%$ \\
2. 小布団 & 79 & $31.0 \%$ \\
3. タオル & 117 & $45.9 \%$ \\
4. 毛布 & 26 & $10.2 \%$ \\
5. クッション & 216 & $84.7 \%$ \\
6. フローテーションパッド & 44 & $17.3 \%$ \\
7. ビーズ & 151 & $59.2 \%$ \\
8. ウレタンスポンジ & 155 & $60.8 \%$ \\
9. ムートン & 46 & $18.0 \%$ \\
10. ロホクッション & 20 & $7.8 \%$ \\
11. その他 & 34 & $13.3 \%$ \\
\hline
\end{tabular}

表12. ベッド上で利用する体位支持用具

\begin{tabular}{lrr}
\hline & 度数 & パーセン \\
\hline 1. 体位支持用具 & 83 & $32.7 \%$ \\
2. 羽枕 & 33 & $13.0 \%$ \\
3. 小布団 & 88 & $34.6 \%$ \\
4. タオル & 106 & $41.7 \%$ \\
5. 毛布 & 34 & $13.4 \%$ \\
6. ウレタンスポンジ & 135 & $53.1 \%$ \\
7. ビーズ & 155 & $61.0 \%$ \\
8. クッション & 228 & $89.8 \%$ \\
9. その他 & 9 & $3.5 \%$ \\
\hline
\end{tabular}

表13. 車椅子又は座位で利用する体位支持用具

\begin{tabular}{lrr}
\hline & 度数 & パーセン \\
\hline 1. 羽枕 & 5 & $2.0 \%$ \\
2. 小布団 & 57 & $22.6 \%$ \\
3. タオル & 47 & $18.7 \%$ \\
4. 毛布 & 5 & $2.0 \%$ \\
5. クッション & 174 & $69.0 \%$ \\
6. フロ一テーションパッド & 49 & $19.4 \%$ \\
7. ビーズ & 44 & $17.5 \%$ \\
8. ウレタンスポンジ & 136 & $54.0 \%$ \\
9. ムートン & 38 & $15.1 \%$ \\
10. ロホクッション & 29 & $11.5 \%$ \\
11. その他 & 31 & $12.3 \%$ \\
\hline
\end{tabular}

表14. 器具利用教育を行うシステム

\begin{tabular}{|c|c|c|c|c|}
\hline & \multicolumn{2}{|c|}{ 家族·本人等 } & \multicolumn{2}{|c|}{ 看護師·介護士等 } \\
\hline & 度数 & パーセン & 度数 & パーセント \\
\hline ある & 22 & $9.0 \%$ & 83 & $33.9 \%$ \\
\hline ない & 222 & $91.0 \%$ & 162 & $66.1 \%$ \\
\hline
\end{tabular}


表15. 利用器具に関する質問

\begin{tabular}{|c|c|c|c|c|}
\hline & \multicolumn{2}{|c|}{ はい } & \multicolumn{2}{|c|}{ いいえ } \\
\hline & 度数 & パーセント & 度数 & パーセント \\
\hline (1) 裖瘡マット(予防/治療) 数は充足していますか & 274 & $51.0 \%$ & 263 & $49.0 \%$ \\
\hline (2)体位変換用枕 (クッション)を用意していますか & 523 & $96.5 \%$ & 19 & $3.5 \%$ \\
\hline （3）車椅子用クッションを用意していますか & 369 & $71.5 \%$ & 147 & $28.5 \%$ \\
\hline (5)クッションの個人利用をすすめていますか & 346 & $65.4 \%$ & 183 & $34.6 \%$ \\
\hline $\begin{array}{l}\text { (6)裖瘡が発生したことで 患者さんないしはご家族 } \\
\text { から苦情を受けた経験はありますか }\end{array}$ & 81 & $15.2 \%$ & 453 & $84.8 \%$ \\
\hline (7)体位変換は行いますか & 554 & $99.8 \%$ & 1 & $0.2 \%$ \\
\hline (8)体位変換のために用具を使いますか & 491 & $90.6 \%$ & 51 & $9.4 \%$ \\
\hline (9)体圧を測ったことがありますか & 185 & $34.3 \%$ & 355 & $65.7 \%$ \\
\hline $\begin{array}{l}\text { (11) 用具を使って看護 介護業務が楽になりました } \\
\text { か }\end{array}$ & 328 & $72.9 \%$ & 122 & $27.1 \%$ \\
\hline $\begin{array}{l}\text { （13）あなたが利用している用具の使用方法について } \\
\text { 研修を受けましたか }\end{array}$ & 170 & $36.5 \%$ & 296 & $63.5 \%$ \\
\hline $\begin{array}{l}\text { (20) あなたは裖瘡対策用具 (ベッドマット·除圧クッ } \\
\text { ションなど)の使用方法について研修を受けたことが } \\
\text { ありますか }\end{array}$ & 229 & $42.3 \%$ & 312 & $57.7 \%$ \\
\hline
\end{tabular}

\section{5. 裖瘡の判定業務}

\section{1. 裖瘡の評価法について}

「保険で決まったフォームで判定しにくいところがあります か」の問いに 133 件の回答を得た。表 16 に緾めた。「2. いい

え」109件と多く，多くが保険で決まったフォーム を利用できることが確認できた。「判定しにくい」 とする者の自由記入には 17 件回答があり, 骨突出 有無についての判定基準 3 件，深さ 2 件，分からな い 2 件，その他栄養状態の低下の基準が不明確，看 護計画が記述式で使いにくいなどがあった。しかし， 評価スケールは，209件の回答から，表 17 に示すと おり, 裤瘡対策の診療計画書での評価方法の設問回 答中 $20 \%$ とまだ浸透していない現状が浮かび上が った。裖瘡対策開始以前から使用していた「2.ブ レーデンスケール」98 件と多いのが確認できた。 ブレーデンスケールや大浦スケールのほうが多い。 80\%の管理者はこの評価法で判定しやすいとして いる現状から乘離が見られる。評価法の定着には時 間が必要と思われた。

\section{2. 日常生活自立度}

実務者(全数)は診療計画書を作成するための寝 たきり度日常生活自立度 $\mathrm{B} ・ \mathrm{C} レ$ レ゙の理解につい
表16. 保険で決まったフォームで判定

\begin{tabular}{lrr}
\hline & 度数 & \multicolumn{1}{c}{ パーセン } \\
\hline 困難(はい) & 24 & $18.0 \%$ \\
いいえ & 109 & $82.0 \%$ \\
\hline
\end{tabular}

表17. 評価で用いるスケール

\begin{tabular}{lrr}
\hline & 度数 & パーセン \\
\hline 1. 保険で決まったフォーム & 42 & $20.1 \%$ \\
2. ブレーデンスケール & 98 & $46.9 \%$ \\
3. 大浦スケール & 45 & $21.5 \%$ \\
4. TIME & 0 & \\
5. その他 & 47 & $22.5 \%$ \\
\hline
\end{tabular}

表18. 日常生活自立度判定基準に関する理解について

\begin{tabular}{lrr}
\hline & 度数 & パーセン卜 \\
\hline 理解している & 287 & $56.7 \%$ \\
分かりづらい & 187 & $37.0 \%$ \\
知らない & 32 & $6.3 \%$ \\
\hline
\end{tabular}

表19. 裖瘡のDESIGN-P分類は判定できますか

\begin{tabular}{lrr}
\hline & 度数 & パーセン \\
\hline 正確にできる & 64 & $12.4 \%$ \\
自信はないがやっている & 269 & $51.9 \%$ \\
よく理解していない & 185 & $35.7 \%$ \\
\hline
\end{tabular}

て，表 18 に示すとおり，43\%が十分に理解していないと答えている。表 19 に示すとおり，裖瘡

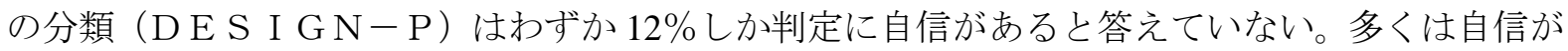
ない中で判定しているというのが現実である。 


\section{3. 裖瘡対策診療計画書 危険因子の判定}

郵送調査と全数調査の有効サンプル数は郵送で 208-213, 全数で 492-504 の回答を得た。郵送回 答の内訳は\%表示で表 20 に示す。イス上での除圧・病的骨突出・関節拘縮・栄養低下・浮腫等で 40\%を超える多くが判定に苦慮している。1 人で判断する時には判定に悩むのが実態ではないだ ろうか。なお，郵送調查回答者は全項目で「やさしい」が，全数調査回答者のパーセントを上回 り，全項目で「むずかしい」が下回っていた。

表20. 危険因子の評価判定の難易について

\begin{tabular}{|c|c|c|c|c|c|c|c|c|}
\hline & \multicolumn{2}{|c|}{ 難しい } & \multicolumn{2}{|c|}{$\begin{array}{c}\text { どちらかといえば } \\
\text { 難しい }\end{array}$} & \multicolumn{2}{|c|}{$\begin{array}{c}\text { どちらかといえば } \\
\text { やさしい }\end{array}$} & \multicolumn{2}{|c|}{ やさしい } \\
\hline & 度数 & $\%$ & 度数 & $\%$ & 度数 & $\%$ & 度数 & $\%$ \\
\hline $\begin{array}{l}\text { 1. 基本的操作能力、ベッド上での体位 } \\
\text { 変換 }\end{array}$ & 26 & $5.2 \%$ & 130 & $26.1 \%$ & 232 & $46.5 \%$ & 111 & $22.2 \%$ \\
\hline 2. イス上での坐位保持、除圧 & 34 & $6.8 \%$ & 196 & $39.4 \%$ & 193 & $38.8 \%$ & 75 & $15.1 \%$ \\
\hline 3. 病的骨突出 & 75 & $15.1 \%$ & 188 & $37.8 \%$ & 160 & $32.1 \%$ & 75 & $15.1 \%$ \\
\hline 4. 関節拘縮 & 85 & $16.9 \%$ & 162 & $32.1 \%$ & 175 & $34.7 \%$ & 82 & $16.3 \%$ \\
\hline 5. 栄養状態低下 & 81 & $16.4 \%$ & 201 & $40.7 \%$ & 151 & $30.6 \%$ & 61 & $12.3 \%$ \\
\hline 6. 皮膚湿潤 (多汗·尿失禁·便失禁) & 39 & $7.9 \%$ & 132 & $26.8 \%$ & 208 & $42.3 \%$ & 113 & $23.0 \%$ \\
\hline 7. 浮腫(局所以外の部位) & 55 & $11.0 \%$ & 167 & $33.4 \%$ & 198 & $39.6 \%$ & 80 & $16.0 \%$ \\
\hline
\end{tabular}

\section{4. 裖瘡対策診療計画書 裖瘡回診}

表 21 に示寸指示の実施状況から見て，裖瘡診療計画書であるが，まだ十分な情報源として現場 で利用されていない。裖瘡のハイリスク患者の把握はまだ申し送りなどの方法でやっている。リ ハビリテーションの実施は 78\% と高い。病棟を回る裖瘡回診の評価は $85 \%$ で有用であると認めて いる。

表21. 裖瘡の予防業務について

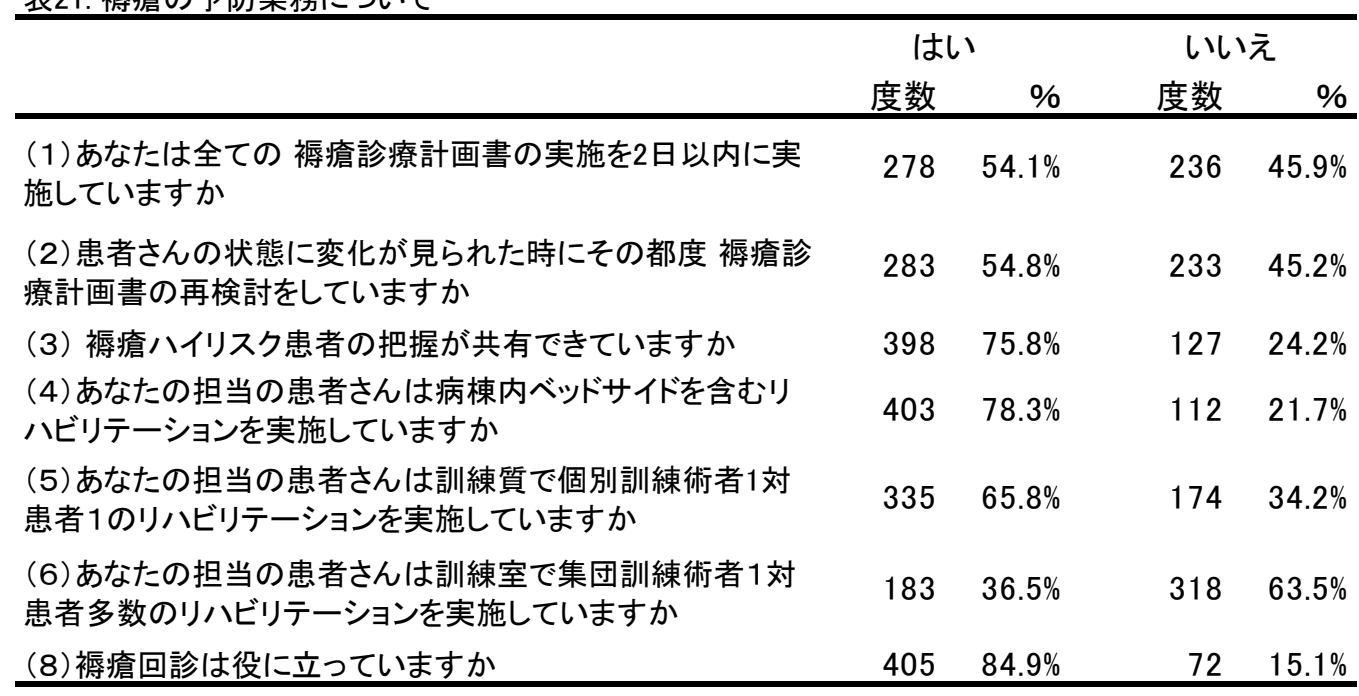

\section{5. 裖瘡の発生について}

「あなたの経験では持ち込み裖瘡と院内発生の裖瘡 ではどちらが多いですか」の問いに対し，郵送調査の 有効サンプルは合計 219 件で, 回答の内訳を表 22 に示 す。裖瘡患者のうち約 7 割は前医からの持ち込みで, 残りの 3 割は院内発生である。郵送調査と全数調査の

表22. 持ち込み裖瘡之院内発生状況

\begin{tabular}{lrr}
\hline & 度数 & \multicolumn{1}{c}{ パーセン } \\
\hline 持ち込み 裖瘡 & 372 & $69.0 \%$ \\
院内発生 裖瘡 & 158 & $29.3 \%$ \\
無回答 & 9 & $1.7 \%$ \\
\hline
\end{tabular}

回答の間に大きな差異は認められない。 


\section{6. 裖瘡患者移動の現状}

裖瘡患者の入退院先について調査した。通説として一般 病院からの裖瘡患者入院が多いと言われるが, 表 23 に現 れている。患者の動きは 急性期一般病院から回復期リ八 病棟を一部通過しながら在宅・療養病棟・介護施設などへ 達する。おそらく昨今の在院日数短縮化に伴い裖瘡の治療 で移動するものというより基礎疾患の治療に付随して動 いていく。また, 裖瘡が治癒してから病院・施設間を移動 するとは限らず, 裖瘡をもって移動するということもあろ う。

「どこへ褯瘡患者が退院していきますか。」について表 24 に䌕めた。自宅へ帰れない者が約 $77 \%$ と多いことがわ かる。

\section{7. 生データの管理方法}

258 件の回答を表 25 に示寸。「2. 診療録」 160 件と多い のが確認できた。今後は電子化が進むものと思われる。
表23. 裖瘡患者入院の1番目先

\begin{tabular}{lrr}
\hline & 度数 & パーセント \\
\hline 1. 自宅/特定機能病院 & 68 & $31.2 \%$ \\
2. 一般病院 & 85 & $39.0 \%$ \\
3. 療養病床を持つ病院 & 19 & $8.7 \%$ \\
4. 介護老人福祉施設 & 24 & $11.0 \%$ \\
5. 介護老人保健施設 & 17 & $7.8 \%$ \\
6. ケアハウス & 1 & $0.5 \%$ \\
8. 介護付き住宅 & 2 & $0.9 \%$ \\
9. その他 & 2 & $0.9 \%$ \\
\hline
\end{tabular}

表24. 裖瘡患者退院の1番目先

\begin{tabular}{lrr}
\hline & 度数 & パーセン \\
\hline 1. 自宅/特定機能病院 & 42 & $22.6 \%$ \\
2. 一般病院 & 25 & $13.4 \%$ \\
3. 療養病床を持つ病院 & 36 & $19.4 \%$ \\
4. 介護老人福祉施設 & 38 & $20.4 \%$ \\
5. 介護老人保健施設 & 36 & $19.4 \%$ \\
7. グループホーム & 1 & $0.5 \%$ \\
9. その他 & 8 & $4.3 \%$ \\
\hline
\end{tabular}

\section{8. 加算の状況} 表25. 生データの管理方法

日常生活自立度 $\mathrm{B} ・ \mathrm{C}$ レベル, 裖瘡危険因子がある場合加算 20 点について, 表 26 に示す回答を得た。 1 月に加算件数は, 約 2 割が 0 件，全体の 6 割が月 10 件以下と低くとれていないところ が多い。しかし，100 件以上も 2 割弱あり，200 件以上は $8 \%$ と十

\begin{tabular}{lrr} 
& 度数 & パーセント \\
\hline 1. 電子カルテ & 29 & $12.2 \%$ \\
2. 診療録 & 160 & $67.2 \%$ \\
3. その他 & 69 & $29.0 \%$ \\
\hline
\end{tabular}
分加算のとれている病院がみられる。少額だが格差は大きい。

長期入院の療養型では患者の動きが少ないが裖瘡発生リスクの高い 寝たきり患者が多いにもかかわらず加算はとれていない。また回答があ った施設の内 $92 \%$ が 500 点加算を取っていない。

\section{9. 裖瘡発生の責任システム}

裖瘡が発生した場合, 何らかの責任をとるシステムについて 211 件の 回答があり，5\%に責任システムが導入されていた。施設は勤務者に裖 瘡発生に関し特に責任を問うていないことが分かった。

表29. 平成14年10月と平成18年10月の1日当りの平 均 裖瘡患者数とその中の院内発生数

\begin{tabular}{|c|c|c|c|c|}
\hline & \multicolumn{2}{|c|}{ 平成14年10月 } & \multicolumn{2}{|c|}{ 平成18年10月 } \\
\hline & $\begin{array}{c}\text { 裖瘡患 } \\
\text { 者数 }\end{array}$ & $\begin{array}{c}\text { 院内発 } \\
\text { 生数 }\end{array}$ & $\begin{array}{c}\text { 裖瘡患 } \\
\text { 者数 }\end{array}$ & $\begin{array}{c}\text { 院内発 } \\
\text { 生数 }\end{array}$ \\
\hline 0件 & 12 & 15 & 16 & 34 \\
\hline 5件以下 & 26 & 49 & 60 & 81 \\
\hline 10件以下 & 22 & 6 & 40 & 24 \\
\hline 20件以下 & 23 & 12 & 37 & 11 \\
\hline 30件以下 & 5 & 1 & 11 & 1 \\
\hline 50件以下 & 7 & 1 & 2 & 1 \\
\hline 80件以下 & 2 & & 1 & \\
\hline 100 件以上 & 1 & & 1 & \\
\hline 合計 & 98 & 84 & 168 & 152 \\
\hline
\end{tabular}

表26. 裖瘡危険因子がある場 合の20点加算

\begin{tabular}{lrr}
\hline & 度数 & \multicolumn{1}{c}{ パーセ卜 } \\
\hline 0件 & 24 & $17.9 \%$ \\
5件以下 & 34 & $25.4 \%$ \\
10件以下 & 21 & $15.7 \%$ \\
20件以下 & 10 & $7.5 \%$ \\
30件以下 & 6 & $4.5 \%$ \\
40件以下 & 6 & $4.5 \%$ \\
50件以下 & 7 & $5.2 \%$ \\
100件以下 & 15 & $11.2 \%$ \\
200件以下 & 6 & $4.5 \%$ \\
201件以上 & 5 & $3.7 \%$ \\
\hline
\end{tabular}

表27. 摂食介助点数の認識

\begin{tabular}{lrr}
\hline & 度数 & パーセン \\
\hline 知っている & 226 & $43.0 \%$ \\
知らない & 299 & $56.8 \%$ \\
空白 & 1 & $0.2 \%$ \\
\hline
\end{tabular}

表28. NST 栄養サポートチーム

\begin{tabular}{lrr}
\hline & 度数 & \multicolumn{1}{c}{ パーセン } \\
\hline 知っている & 387 & $71.8 \%$ \\
知らない & 151 & 28.0 \\
空白 & 1 & $0.2 \%$ \\
\hline
\end{tabular}




\section{6. 栄養}

\section{1. 摂食介助}

栄養を取るにははまず食べることを援助することか らで，摂食介助は大事な看護業務である。摂食介助を すれば 1 日 185 点の加算があるが，このことを表 27 に示すように現場が周知していない。摂食介助を必要 と判断されるケースに援助をしながら 185 点の点数加 算を現場の半数が知らないのは施設が知らせていな いと思われ，摂食介助をしていながら，施設経営に反 映していない面もあるのではないかと思われる。

\section{表30. 平成14年10月と平成18年10月の裖瘡} の治癒率と軽快率 平成14年10月 平成18年10月 治癒率 軽快率 治癒率 軽快率

\begin{tabular}{lrrrr}
\hline $0 \%$ & 10 & 7 & 11 & 9 \\
$10 \%$ 以下 & 10 & 4 & 16 & 8 \\
$30 \%$ 以下 & 12 & 10 & 24 & 13 \\
$50 \%$ 以下 & 8 & 11 & 17 & 19 \\
$70 \%$ 以下 & 7 & 3 & 13 & 10 \\
$99 \%$ 以下 & 7 & 7 & 12 & 8 \\
$100 \%$ & 6 & 3 & 14 & 12 \\
合計 & 60 & 45 & 107 & 79 \\
\hline
\end{tabular}

\subsection{NST（栄養サポートチーム）}

NST は裖瘡対策と同時期に臨床現場に広まってきた。 非常に重要であると評価されている半面，表 28 に示す ように，まだNST を知らないと実務者の $28 \%$ 答えて いる。N S Tの体制ができていない医療機関があり， その場合N S T が栄養管理に有用であると知らなかっ たと答えている。

\section{7. 裖瘡対策未実施減産制度導入の効果}

\section{1. 裖瘡対策未実施減産制度について現場の実感}

「12. 過去のデータに関して, 可能な範囲でお答えください。」 表31. 過去のデータ管理の状況

\begin{tabular}{lrr} 
& 度数 & パーセ卜 \\
\hline $\begin{array}{l}\text { 1. 平成18年10月のデータ } \\
\text { がある }\end{array}$ & 71 & $42.3 \%$ \\
$\begin{array}{l}\text { 2. 平成14年10月のデータ } \\
\text { がある }\end{array}$ & 97 & $57.7 \%$ \\
\hline
\end{tabular}
と設問した。平成 14 年 10 月と 平成 18 年 10 月の裖瘡発生数に 関し回答を表 29-31 に纏めた。「1. 平成 18 年 10 月のデータ」の回 答数は 71 件, 「2. 平成 14 年 10 月と平成 18 年 10 月のデータ」 の回答数 97 件であった。回答全 体のうちの $42 \%$ の施設が裖瘡発 生に対し，管理強化しているこ とが分かる。「2. 平成 14 年 10 月と平成 18 年 10 月のデータ」 については Wilcoxon の符号付

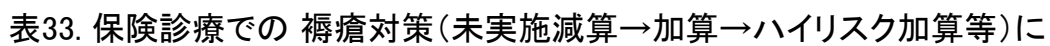
関して

表32. 裖瘡ありの人数の変化

\begin{tabular}{lrr}
\hline & 度数 & パーセン \\
\hline 減少認識 & 136 & $76.4 \%$ \\
減少認識なし & 42 & $23.6 \%$ \\
\hline
\end{tabular}

き順位検定をおこない，裖瘡患者数（ $Z=-2.733 ＼mathrm{~ ， 漸 近 優 位 確 率 （ 両 側 ） ~} 0.006 ） ，$ 院内発生数 $(Z$ $=-2.656$, 漸近優位確率（両側） 0.008 ） とも，平成 14 年 10 月の数值から平成 18 年 10 月の数值 の間で有意に減少していた。また 76\%を超える減少したとの回答があった。

\section{2. 裖瘡対策未実施減産制度について現場の実感 2}

「未実施減産制度の委員会設置時評価で裖瘡ありの人数からアンケート回答時の直近の委員会 での裖瘡（潰瘍形成）ありの人数で比べると人数は減りましたか?」の設問に対し，「1.はい」の 回答数は 136 件と多く, 設問自体から厚生労働行政の成果評価になっている。表 32 に示すとおり 郵送回答者の $76 \%$ を超える実務者が，患者を減少させることができたと回答した。裖瘡対策未実 施減産制度導入の成果が明らかになったといえる。 


\section{3. 現場の印象（仕事量の増加・成果）}

現場の印象は，表 33 に示すとおり， 裖瘡対策開始前に比べて半数は仕事 に変化を認識しており，つまり仕事量がふえたと答えている。しかし，裖瘡対策に必要な用具は 確実に増え，その甲斐あって裖瘡患者は減ったと実感しているものが全体のなんと 8 割がいるこ とも分かった。現場では仕事量は増えたが裖瘡患者を減らすことになった。

\section{8. 考察}

裖瘡対策は，医療・介護の分野に大きな変化をもたらし，裖瘡はつきものといった諦めの気持 ちや半ば経験だけを武器に対処していたこれまでの医療現場には衝撃を与えた。管理者もこれま でのように現場に丸投げでは済まなくなった訳である。一方，現場は未だまだ科学的分析には不 慣れであることが分かった。医療関係者や介護の実務に当たる者には基礎的な評価のトレーニン グの必要がある。この対策が形骸化に終わることなく更に進化する努力が必要とされている。

また今回の 2 件の研究が実施可能になったことにより, 長岡らは, 「コジャックの法則（局所 圧力 $200 \mathrm{mmHg}$ 以下・2 時間以内の体位変換）に則して，体位変換を実施すれば裖瘡の発生を見 ない」を実現した病院の状況について報告した。またテクノエイド協会の審査会で，自然言語処 理の発展により実用的な水準の分析が可能となったテキストマイニングによる分析を研究班から 提案した。この分析により，村上らはこれまでの研究では明らかにならなかった用具の特異的な 利用について明らかにした。滝沢らはリハビリテーションの視点から分析を試み, その実施プロ グラムの合理性を明らかにした。

\section{9. 結語}

裖瘡対策未実施減算から始まって現在に至る医療現場そして介護老人保健施設の裖瘡対策の変 化について全国規模と地域の病院の看護師を対象に調查をした。現場の印象では，「裖瘡対策は確 実に裖瘡患者の減少・軽度化に帰依した。と結論している。実際には高度なレベルの知識や治療 より基本的な合意事項が現場で普遍的になっていないことのほうが問題として浮かび上がった。 より高度な医療より患者の全身状態や局所の観察を正確に行い記録に残していくという当たり前 の看護・介護業務の徹底が，裖瘡対策でまず解決すべき今後の課題だと思われた。

今回の研究調査の結果, 研究班の全員, 我々医療者, 特に学会, 専門誌を通し十分情報を得る 機会のある医療のリーダーである医師及び実践の場にある看護師にとって大きな反省の機会を得 ることが出来た。学会活動等或いは教育活動を通して裖瘡の予防或いは治療薬剤等についても十 分知識として常識化していたと信じている。しかし一向に裖瘡の予防に本腰が入らず医療者の全 てが諦めにも似た「仕方の無いこと」として目を瞑ってきた。その結果，40 年を経ても，医療の 現場での裖瘡発生に大きな改善は認められなかった。しかし，行政の医療への介入で，見事に医 療者全体が目覚め, あたかもお叱りの効果が現れた如く, 分かっていたことを実行しなかった事 に対する医療者に猛省を促寸結果になったことは，医療に携わる者として，大変残念乍ら拍手を 以って絶賛せざるを得ない。知識を持ってはいたが「実行できなかった」のではなく，「実行しな かった」と言うに他ならないことが検証されたと言うことである。他に斯様な事例が出来しない ことを望まざるを得ない。我々の研究グループの長岡班の如く従前から予防処置を通常業務とし て，厚労省の指針とほぼ同等の行為を行なっていた医療機関はごく稀であったと言わざるを得な い。

\section{参考文献}

1）木村哲彦,今井銀四,金子仁,光田健児（1968）対麻痺患者における陳旧性裖創の検索一第 1 報 悪 性腫瘍発生母地としての裖創,P791-796,医療第 22 巻第 7 号. 
2) 木村哲彦,富田忠良,今井銀四郎,松尾明,光田健児 (1969) 対麻痺患者における陳旧性裖創の検索, 第 2 報＼cjkstart体圧分布と裖創好発部位との関係について,pp48-54,医療第 23 巻 11 号.

3) KOSIAK, M. (1961). The etiology of decubitus ulcers.Arch. Phys. Med. Rehabil, 4 2, 19 - 29.

4) 木村哲彦，(1975-76）裖㾑の病理・予防・治療，1）-12）, 看護学雑誌，vol.39（2）～40（1）.

5）木村哲彦,裖瘡の治療と予防, P31-35,SEIKEI-GEKA KANGO Vol.2 No.5(463).

6) 木村哲彦,裷瘡とは,看護学雑誌, P175, vol.39 no.2,1975 年 2 月

7) 木村哲彦,裖瘡好発部位等高線撮影法および体圧分布による解析, 看護学雑誌, P289, vol.39 no.3 1975 年 3 月.

8) 木村哲彦,裖瘡の病理・予防・治療一原因,特に物理的持続圧迫以外のもの,看護学雑誌, P391, vol.39 no.4 1975 年 4 月.

9）木村哲彦,陳旧性の裖瘡と悪性腫瘍陳旧性の裖瘡は悪性腫瘍の発生母地ともなり得る,看護学 雑誌, P509, vol.39 no.5 1975 年 5 月.

10) 木村哲彦,座り方と好発部位との関係 春髄性対麻庫・四肢麻痺の場合,看護学杂倠誌，P611, vol.39 No.6, 1975 年 6 月.

11) 木村哲彦,予防および一般的非観血的治療, 看護学杂倠誌, P713, vol.39 no.7 1975 年 7 月.

12) 木村哲彦,裖瘡予防・治療のためのベッドおよびクッション材,看護学雑誌, P815, vol.39, no.8 1975 年 8 月。

13）木村哲彦,難治性䙏瘡の症例巨大裖瘡・多発䙏瘡, 看護学雑誌, P1029, vol.39 no.10 1975 年 10 月.

14）木村哲彦,仙骨部の難治性裖瘡例ほか,看護学雑誌, P1137，vol.39 no.11 1975 年 11 月.

15）木村哲彦,症例一特に高年齢の場合,看護学雑誌, P1241, vol.39 no.12 1975 年 12 月.

16）木村哲彦,治療のコツおよび患者・家族に対する指導の要点,看護学杂倠誌, P77, vol.40 no.1 1976 年 1 月。

17）木村哲彦・橋倉一裕・初山泰弘・渡辺修身・鈴木正彦・武田功・川井伸夫,特集 /春髄損傷の リハビリテーション車椅子用クッションに関する工夫,P388＼cjkstart総合リハ 1976 年 5 月.

18）木村哲彦,皮膚の湿潤・不潔・摩擦，栄養と裖瘡予防,臨牀看護, P477, April 1990 へる寸出版.

19）木村哲彦,平成 17-18 年度木村哲彦,緒言,裖瘡対策未実施減算導入後の裖瘡に関寸る研究 （17590458）報告書.

20) 木村哲彦,平成 18-19 年度財団法人テクノエイド協会福祉用具研究開発事業-調查研究関係-研 究報告書.

21）長岡健太郎・木村哲彦・森田能子・滝沢茂男, 座位姿勢保持と裖瘡予防に適応する 5 角クッショ ンの開発と利用，PP5-8，バイオフィリアリハビリテーション研究(4)，（2007 年）（查読論文）.

22）滝沢茂男,武藤佳恭,木村哲彦,牛澤賢二,滝沢恭子,長岡健太郎, 裖瘡予防とリハビリテーション実施 に関する研究，PP11-18，バイオフィリアリハビリテーション研究(5)，（2009 年）（查読論文）

23）村上亜紀，滝沢茂男，木村哲彦，森田能子,長岡健太郎（2008）裖瘡予防における福祉用具の役割 とその利用の実際の研究, PP1-10, バイオフィリア リハビリテーション研究(5), (2009 年)（查読 論文）。

24）長岡健太郎, 木村哲彦, 滝沢茂男, 牛澤賢二, 山下和彦, 村尾俊明, 岡本雄三(2006)裖瘡対策未実 施減算導入後の䘠瘡に関する研究，第 10 回バイオフィリア リハビリテーション学会予稿集 22 . 
25）長岡健太郎他, 裖瘡対策未実施減算導入後の裖瘡に関する研究, バイオフィリアリハビリテ ーション研究 Vol. 6(2010) No. 1 P35-42.

\section{謝辞}

この研究は「平成 17-18 年度 科学研究費補助金（基盤（C)）（17590458）「裖瘡対策未実施減算 導入後の裖瘡」」及び「平成 18-19 年度 財団法人テクノエイド協会助成調查研究事業「裷瘡予防 における福祉用具の役割とその利用の実際の研究」」の助成により行った。これら研究費の助成が 本研究を可能にした。又滝沢茂男氏を始め研究実務に尽力いただいた関係各位に深甚な感謝を申 し上げる。 